\title{
Worker Education Training Program
}

National Cancer Institute

\section{Source}

National Cancer Institute. Worker Education Training Program. NCI Thesaurus. Code C82636.

In conjunction with 20 awardees, this prog ram supports the development of curricula and initiation of training programs throug hout the country to help employers meet Occupational Safety and Health Administration (OSHA) requirements under CFR 1910.120, Hazardous Waste Operations \& Emergency Response. 